\title{
JURNALIS PEREMPUAN DAN CITIZEN JURNALISM
}

\author{
Nurul Qomariah, \\ Wartawan Tribun Pekanbaru \\ Nurul_tribunpekanbaru@yahoo.com
}

\begin{abstract}
Undeniable, that the amount of women journalist in printed media or electronic media is very limited in comparison with men journalist. As a result, more women only become news sources to a media. This article discuss why does the amount of women journalist is very limited and what the alternative that can be done to push women more active as journalist. From the analysis that have been done, it founf that the cause of the limited amount of women journalist is more women do not understand the benefit of writing to her self and women have limited time to pour her mind in writing, although she is anxious to write. The limitation of women journalist can be overcome throuh te citizen of journalism.
\end{abstract}

Kata Kunci: jurnalis perempuan, citizen journalism, media

\section{PENDAHULUAN}

Di negara-negara maju, perempuan yang berprofesi sebagai jurnalis jumlahnya sudah lumayan, sekitar 30\%-40\%, bahkan di Finlandia mencapai angka 49\%. Dari sejumlah negara maju, memang hanya Jepang menurut NIPPRO (Japanese Broadcasting Labour Union), yang memiliki hanya 850 jurnalis perempuan dan 9500 jurnalis laki-laki. Namun, Jepang mempunyai jurnalis perempuan handal bernama Yayori Matsui. Ia seorang jurnalis dan aktivis yang memiliki komitmen tinggi terhadap isu-isu perempuan. Berbagai masalah perempuan terutama mengenai perempuan Asia, mulai dari perdagangan 
perempuan dan anak hingga soal globalisasi dan dampaknya terhadap perempuan ditulis dengan gamblang.

Matsui terus menulis menyuarakan ketidakadilan yang dihadapi perempuan Asia hingga akhir hayatnya di usia 68 tahun. Ia meninggal pada tanggal 27 Desember 2002. Jurnalis perempuan lain yang patut dicatat oleh sejarah adalah Susan Faludi, pemenang penghargaan Pulitzer yang memfokuskan diri pada isu-isu perempuan. Karyanya Backlash, 1992, mempersoalkan representasi perempuan oleh media secara negatif. Ia pun bicara mengenai soal feminisme dan kemajuan-kemajuan yang telah diperjuangkan perempuan.

Berbeda dengan Indonesia, profesi sebagai jurnalis sepertinya belum terlalu popular di kalangan perempuan, jika dibandingkan dengan profesi lain seperti guru, dokter, maupun artis. Sungguhpun perkembangan media massa begitu pesat pada era reformasi, keterlibatan perempuan dalam bidang tersebut belum menunjukkan presentase memuaskan. Indikator ini dapat dilihat antara lain dalam susunan struktural sebuah media di mana kurang sekali nama perempuan dalam jajaran redaksi. Akibatnya, pemberitaan media terhadap perempuan menjadi kurang objektif. Tulisan ini antara lain akan membahas mengapa terbatas jumlah jurnalis perempuan dan alternatif apa yang dapat dilakukan untuk mendorong perempuan aktif sebagai jurnalis.

\section{PEMBAHASAN}

\section{Perkembangan Media Massa}

Pada awalnya, penyebaran informasi yang dilakukan oleh manusia hanya melalui mulut ke mulut. Seiring dengan perkembangan zaman di mana mesin cetak telah ditemukan oleh Johannes Gutenberg, penyebaran informasi mulai diambil oleh media massa. Media massa atau pers adalah suatu istilah yang mulai dipergunakan pada tahun 1920-an untuk mengistilahkan jenis media yang secara khusus didesain untuk mencapai masyarakat yang sangat luas. Dalam pembicaraan sehari-hari, istilah ini sering disingkat menjadi media. $^{1}$

Ada dua jenis media massa, yaitu media massa tradisional dan modern. Media massa tradisional adalah media massa dengan otoritas dan memiliki organisasi yang jelas sebagai media massa. ${ }^{2}$ Secara tradisional media ini digolongkan sebagai berikut: surat kabar, majalah, radio, televisi, film (layar lebar). Dalam jenis media ini terdapat ciri-ciri seperti: (1) Informasi dari lingkungan diseleksi, diterjemahkan dan didistribusikan, (2) Media massa menjadi perantara dan mengirim informasinya melalui saluran tertentu, (3) Penerima pesan tidak pasif dan merupakan bagian dari masyarakat dan menyeleksi informasi yang mereka terima, dan (4) Interaksi antara sumber berita dan penerima sedikit. 
Media massa modern, memiliki ciri-ciri (1) Sumber dapat mentransmisikan pesannya kepada banyak penerima (melalui SMS atau internet misalnya), (2) Isi pesan tidak hanya disediakan oleh lembaga atau organisasi namun juga oleh individual, (3)Tidak ada perantara, interaksi terjadi pada individu, (4) Komunikasi mengalir (berlangsung) ke dalam, dan (5) Penerima yang menentukan waktu interaksi. ${ }^{3}$

Orang yang aktif di media massa disebut jurnalis. Di Indonesia, perkembangan kegiatan jurnalistik diawali oleh Belanda. Beberapa pejuang kemerdekaan menggunakan jurnalisme sebagai alat perjuangan. Di era-era inilah muncul 4 Bintang Timur, Bintang Barat, Java Bode, Medan Prijaji, dan Java Bode. Pada masa penjajahan Jepang mengambil alih kekuasaan, korankoran ini dilarang. Tetapi pada akhirnya ada lima media yang mendapat izin terbit, yaitu, Asia Raja, Tjahaja, Sinar Baru, Sinar Matahari, dan Suara Asia.

Kemerdekaan Indonesia membawa berkah bagi jurnalisme. Pemerintah Indonesia menggunakan Radio Republik Indonesia sebagai media komunikasi. Menjelang penyelenggaraan Asian Games IV, pemerintah memasukkan proyek televisi. Sejak tahun 1962 inilah Televisi Republik Indonesia muncul dengan teknologi layar hitam putih.

Masa kekuasaan presiden Soeharto, merupakan masa suram bagi media massa, hal ini terjadi akibat adanya kontrol yang berlebihan dari pemerintah melalui Departemen Penerangan dan Persatuan Wartawan Indonesia (PWI). Pers diharapkan perannya sebagai mitra pemerintah yang hanya menyuarakan suara pemerintah, oleh sebab itu, jarang sekali pers yang berani mengkritik pemerintah. Kontrol yang dominan ini dibuktikan dengan pencabutan Surat Izin Usaha Penerbitan Pers (SIUPP). Bahkan para pejabat pemerintah tak segansegan memberi peringatan kepada pers yang dianggap terlalu berani kepada pemerintah. Akibatnya, banyak media massa dibredel.

Titik kebebasan pers mulai terasa lagi saat BJ Habibie menggantikan Soeharto. Media massa seperti dapat napas baru setelah selama 32 tahun terpasung sehingga banyak media yang bermunculan dan Persatuan Wartawan Indonesia (PWI) tidak lagi menjadi satu-satunya organisasi profesi bagi wartawan. ${ }^{5}$ Sayangnya, ketika media massa di negeri ini menikmati era kebebasan, idealisme dan kebebasan terkadang salah kaprah dan malah kelewat batas. Banyak media yang hanya menyodorkan sensasi sehingga berkembang di jalur keliaran yang tak lagi mencerminkan budaya Indonesia yang sopan dan religius. Tulisan-tulisan di media yang sebelumnya lebih menyuarakan kepada pembebasan mulai bergeser ke arah hedonisme dan komersialisme.

Seiring dengan perkembangan teknologi, khususnya teknologi informasi, perkembangan media menjadi lebih canggih. Media-media baru (internet) yang mulai bermunculan mampu menggeser posisi media konvensional dalam menyampaikan informasi kepada khalayak. Dengan 
mengakses media online di internet, dalam sekejap mata orang bisa mendapatkan informasi dan melakukan apapun, dunia serasa tanpa batas. Media online adalah suatu situs atau halaman dalam internet yang berfungsi untuk memberikan informasi kepada khalayak umum yang terbiasa menggunakan internet/jejaring sosial. Kelebihan mendapatkan informasi dengan media online yaitu :(1) Informasi dapat diterima lebih cepat, (2) Lebih efisien, tidak perlu membeli media cetak seperti koran dan majalah, (3) Informasi yang didapatkan dapat jauh lebih banyak, dan (4) Waktunya fleksibel tanpa batas.

\section{Jurnalis Perempuan dalam Perkembangan Media}

Sejak tahun 1904, sudah mulai muncul jurnalis perempuan seiring dengan bermunculannya media khusus perempuan. Kebanyakan mereka adalah para aktivis organisasi perempuan pada zaman itu yang memakai bahasa tulisan untuk menggugah kesadaran bangsanya. Kecuali masalah kerumahtanggaan, pendirian perempuan yang sesuai dengan nilai-nilai baru seperti poligami, perkawinan, dan kesusilaan, mendapat sorotan tajam. Pada umumnya mereka menyuarakan gagasan, perjuangan dan persamaan gender yang dimuat dalam media cetak seperti surat kabar, majalah, buletin, dan lainnya. Peran pers antara lain sebagai pelapor (informer), yaitu bertindak sebagai mata dan telinga publik, dijalankan oleh para jurnalis perempuan. ${ }^{6} \mathrm{Di}$ sinilah jurnalis harus melaporkan peristiwa-peristiwa yang di luar pengetahuan masyarakat dengan netral tanpa prasangka.

Memang tidak mudah untuk mengungkap keberadaan majalah perempuan pertama di Tanah Air. Myra Sidharta, peneliti sastra Tionghoa, beranggapan bahwa majalah perempuan pertama adalah Tiong Hwa Wi Sien Po, yang terbit pada 1906 dan diasuh seorang perempuan peranakan, Lien Titie Nio. Menyusul terbit adalah majalah perempuan Poeteri Hindia yang dipimpin R. T. A. Tirtokoesoemo, Bupati Karanganyar, yang kemudian menjadi Ketua Perkumpulan Boedi Oetomo. Satu majalah dwimingguan dengan nama yang sama diterbitkan setahun kemudian oleh Javasche Bookhandel yang berpusat di Buitenzoerg alias Bogor.Ternyata semangat menyuarakan idealisme dalam bentuk tulisan berkembang hingga ke luar Jawa. Soenting Melajoe, surat kabar perempuan tertua di Padang, terbit pertama kali pada 6 Juli 1912. Surat kabar mingguan (beredar delapan hari sekali) ini diterbitkan oleh Snelpersdrukkerij "Orang Alam Minangkabau", dipimpin Datoe Soetan Maharadja.

Kendati mengupas masalah perempuan, Datoe Soetan Maharadja menggunakan Soenting Melajoe untuk mengkritik pemerintah Belanda serta para bangsawan. Tidak hanya bertutur secara lugas, tetapi diselingi syair- syair dan pantun-pantun yang digemari masyarakat Minangkabau. Selain Soenting Melajoe, di Padang terbit pula majalah Kaoetaman Isteri Minangkabaoe. Pada 
masa yang sama, juga terbit majalah Eva yang mengklaim sebagai majalah bergambar bagi kaum perempuan (geillustrated blaad voor de vrouw).

Warna lokal majalah perempuan juga tampak dalam Perempuan Sworo yang terbit di Pacitan, Jawa Timur. Prinsip-prinsip kemajuan perempuan dalam majalah yang dipimpin R. A. Siti Soendari ini disampaikan dalam aksara Jawa. Tak jauh berbeda, Hesti Oetama, majalah perempuan dwimingguan yang terbit di Solo pada 1918 juga menggunakan bahasa dan tulisan Jawa.

Bagi perempuan peranakan Belanda, diterbitkanlah majalah berbahasa Belanda, yakni Maanblaad van de Vereeniging voor Vrouwenkiesrecht in Nederlandsch Indie dan Maanblaad van de Vereeniging voor Vrouwenrechts in Nederlandsch Indie. Sementara buat perempuan keturunan Arab, terbit majalah bulanan Isteri Worosoesilo, 1918, yang menggunakan aksara dan bahasa Arab serta tidak berilustrasi.

Puncak euforia majalah perempuan era 20-an ditandai munculnya Doenia Isteri, dwimingguan yang mengaku soerat chabar perempoean yang esa di Hindia ini. Dicetak pertama kali dengan teknik handset serta berhias foto hitam putih, pada 1922 Doenia Isteri mendorong kemajuan yang berguna untuk kaum perempuan. Euforia majalah perempuan mulai surut seiring dengan munculnya zaman pendudukan Jepang. Pelarangan organisasi perempuan, kecuali mereka yang menyokong Jepang, membuat penerbitan majalah perempuan kurang menonjol. Sejumlah majalah perempuan diberangus.

Memecah kevakuman majalah perempuan, Ani Idrus, pemilik surat kabar Waspada, mendirikan Doenia Perempuan yang dibiayai dengan uang belanjanya sendiri. Majalah yang berdiri pada 15 Juni 1949 di Medan ini tergolong radikal dan berani meninggalkan pemikiran konservatif dunia perempuan yang tak beranjak dari urusan dapur dan rumah tangga. Sejak awal Doenia Perempuan mengecam pelarangan bagi kaum perempuan yang ingin menggeluti dunia publik. ${ }^{7}$ Profesi sebagai jurnalis bagi perempuan ketika itu tidaklah mudah. Mereka patut diberi apresiasi. Seperti dalam bidang apapun yang digeluti perempuan, para jurnalis perempuan selalu harus berjuang untuk dapat eksis dalam profesi mereka, baik secara struktur, isi maupun penampilan. Mereka sebagian besar adalah pembawa suara perubahan sosial menuju masyarakat yang berkeadilan gender.

\section{Media Massa pada Masa Reformasi}

Era reformasi dan kemajuan tehnologi memberikan dampak positif dan negatif pada perkembangan media massa. Dampak negatif jelas dapat terlihat ketika kecenderungan ideologi majalah khususnya majalah perempuan mengalami perubahan. Banyak media massa perempuan menjadikan perempuan sebagai bahan berita. Gaya dan selera perempuan ideal, yang semula dianggap otoritas perempuan menengah ke atas, mulai dipopulerkan. Mereka mengemas citra perempuan ideal dari penampilan busana hingga 
keterampilan merawat tubuh. Kendati sesekali menyuarakan pembebasan perempuan, namun kurang berani memaparkan ideologi gender secara transparan. Bahkan mereka menggiring pembaca mengumbar nafsu konsumtif alias mengikuti kemewahan yang tak terbendung, seiring melambungnya sistem ekonomi kapitalistis.

Kecenderungan hedonistis itu nyaris melekati majalah-majalah perempuan yang beredar hingga kini. Kemewahan dan eksploitasi keindahan tubuh perempuan menjadi daya tarik utama setiap edisinya. Tak sedikit gaya berpakaian dan aksesoris dengan harga selangit menghiasi halaman-halaman majalah perempuan. Mereka menciptakan trend dan gaya yang mau tidak mau akan diikuti kaum perempuan yang membacanya sebagai panduan. Para pelaku media sendiri kurang berani menyuarakan kesetaraan gender. Mereka khawatir sajian itu kurang digemari, sehingga majalah miliknya tidak dibeli di pasaran. Isu-isu perempuan tidak laku, dibandingkan dengan misalnya soal perselingkuhan atau gosip para selebritis. Mereka terus mencetak tren-tren baru, sesuai mobilitas dan gaya hidup perempuan kota. Para pelaku media ini terus mereka-reka, apa yang dipikir orang mengenai gaya hidup kelas menengah ke atas. Citra perempuan ideal dikonstruksikan secara fisik. Tanpa sadar perempuan menjadi budak komersialisme. Tragisnya, majalah atau tabloid perempuan justru tak segan menjual seksualitas. Jarang sebuah media perempuan berani menyuarakan ideologi yang berpihak kepada nasib perempuan, khususnya menengah ke bawah atau biasa disebut grassroot (akar rumput).

Dalam cengkeraman ekonomi pasar, media massa cuma menjadi wahana budaya konsumtif dan hedonis. Ia berwatak komersial, bahkan menjadi budak komersialisme. Apa yang menguntungkan dan digemari publik, itulah yang harus diperdagangkan. Tidak heran bila majalah perempuan ogahogahan menawarkan wacana kesetaraan gender. Bukan hanya enggan menyuarakan idealisme perempuan, media massa juga menghadirkan iklan yang mengeksploitasi perempuan. Tak bisa dipungkiri iklan sangat penting bagi media massa. Bahkan pendapatan iklan merupakan penyokong dana utama bagi sebagian media massa untuk kelangsungan kiprahnya. Saking kreatif dan berebutnya penggiat iklan di media massa, seringkali menjadikan perempuan objek dalam bungkus kemajuan, trend, dan gaya hidup. Hal inilah yang nantinya akan berpengaruh mencetak perempuan yang akan terkungkung dalam dunia hedonis dan penampilan fisik semata sebagai gambaran perempuan ideal yang disodorkan media massa

Dengan kondisi seperti itu diperlukan jurnalis-jurnalis perempuan yang mau menjunjung idealisme bukan hanya mengikuti kemauan pasar saja. Peran media yang mendidik benar-benar sangat diperlukan untuk mendongkrak dan mengangkat martabat kaum perempuan, bukan menjadikan perempuan hanya sebagai barang eksploitasi bagi media. Seharusnya keberadaan media dapat 
dijadikan sarana bagi perempuan untuk menuangkan ekspresi dan kreasinya dalam kehidupan bermasyarakat dengan kemampuan intelektual yang dimiliki perempuan.

Dampak positif era reformasi dan kemajuan tehnologi antara lain adalah khalayak pengakses media (pembaca) dapat dengan mudah mendapatkan informasi yang diinginkan di komputer yang sudah dilengkapi dengan aplikasi internet yang terbukti mampu menjadi perantara dalam pengiriman informasi media kepada khalayaknya. Media internet yang bersifat global, memungkinkan masyarakat di wilayah manapun tetap dapat mengakses informasi atau berita terbaru. Keterbatasan ruang dan waktu merupakan hambatan yang sering dihadapi ketika kita harus menyiarkan informasi secara aktual. Dengan adanya internet up-date informasi terbaru lebih mudah dengan ruang yang lebih luas. Media internet bisa menjadi ajang berkreasi dan meningkatkan keterampilan menulis, khususnya bagi kaum perempuan. Menulis bukan hanya bakat tapi bisa dipelajari dan dilatih. Hanya saja, jarang perempuan memiliki keinginan untuk menulis secara serius. Bila diperhatikan di surat-surat kabar, baik lokal maupun nasional, khususnya di rubrik opini, sangat jarang ada tulisan perempuan. Kalaupun ada, mungkin hanya satu atau dua dalam satu bulan. Selebihnya tulisan-tulisan tersebut adalah tulisan para kaum laki-laki. Bahkan, persoalan kaum perempuan ditulis oleh laki-laki.

Dari beberapa penelitian yang dilakukan menunjukkan bahwa alasan yang diberikan para perempuan, ketika ditanyakan mengapa mereka jarang atau tidak mau menulis di media masa antara lain adalah perempuan tidak memahami apa manfaat menulis bagi diri mereka dan beban kerja perempuan di rumah cukup berat sehingga membuat mereka tidak mempunyai waktu untuk menuangkan pikiran secara tertulis, meskipun mereka sangat ingin untuk menulis. Di samping harus mengerjakan pekerjaaan rumah tangga, kebanyakan perempuan harus melakukan kegiatan lain di luar rumah. Mencari nafkah tambahan, karena pendapatan suami yang tidak mencukupi kebutuhan rumah tangga sehari-hari. Belum lagi kalau perempuan harus ikut bergabung dalam organisasi atau kegiatan sosial. Tak kalah berpengaruh perempuan jarang dan malas membaca.

\section{Citizen Journalism dan Kelangkaan Jurnalis Perempuan}

Kemajuan teknologi belakangan ini membuat tempat dan waktu seakan tak terbatas. Berkaitan dengan proses penyebaran informasi yang dahulu dilakukan para jurnalis mainstream media (media utama) seperti wartawan televisi, radio, dan media cetak, sekarang sudah bisa dilakukan oleh siapa saja. Masyarakat yang selama ini dipersepsikan sebagai kelompok konsumen media sekarang bisa bertindak sebagai jurnalis. Meskipun masih menimbulkan pro dan kontra munculnya citizen journalism (jurnalisme warga) menjadi keniscayaan adanya revolusi dalam penyebaran informasi. ${ }^{8}$ Dengan internet, 
semua orang bisa menjadi jurnalis. Jurnalis dalam arti proses pencarian, pengolahan, penulisan, dan penyebaran info yang bisa dilakukan semua orang melalui jalur internet. Leslie David Simon menyatakan bahwa internet dapat membuat setiap orang menjadi penerbit dengan pembaca yang luas.

Dapatkah internet memberdayakan warga dan konsumen dengan menyediakan pengetahuan? Pernyataan ini relevan jika melihat fenomena citizen journalism yang ditawarkan media online, dan menjadi salah satu keunggulan dibandingkan media konvensional seperti media cetak. Citizen Journalism atau dalam pengertian bahasa Indonesia disebut dengan jurnalisme warga mulai berkembang di Indonesia bersamaan dengan berkembangnya media online termasuk blog. Perkembangan di Asia sendiri di mulai pada tahun 2004. Berkembangnya citizen journalism membuat masyarakat mempunyai banyak alternatif berita dan perspektif tentang sebuah hal dari berbagai pihak, sehingga kini kita tidak perlu lagi melokalisir suatu pekerjaan hanya dengan satu profesi tertentu. Kesempatan ini bisa dimanfaatkan kaum perempuan untuk menuangkan gagasan, idealisme untuk kemajuan kaum perempuan. Sarana internet yang memiliki dunia tanpa batas bisa dijadikan media untuk menciptakan tulisan-tulisan yang bermanfaat khususnya bagi perkembangan kaum perempuan.

Citizen Journalism atau jurnalisme warga adalah istilah yang dipakai untuk menjelaskan aktivitas pencarian, pemrosesan, sampai pada penyajian berita kepada khalayak yang semuanya dilakukan oleh masyarakat awam atau non wartawan. Berkembangnya jurnalisme warga membuat masyarakat mempunyai banyak alternatif berita dan perspektif tentang sebuah hal atau informasi dari berbagai pihak karena proses interaksi yang terjalin di sini.

Adapun prinsip citizen journalism, menurut David K. Perry di antaranya (1) Mengusahakan situasi koran dan para jurnalis sebagai partisipan aktif dalam kehidupan kelompok karena akan lebih baik dan tidak memihak, (2) Membuat koran, forum untuk diskusi dari isu-isu yang ada dalam kelompok, (3) Melayani isu ataupun kegiatan dan masalah-masalah penting bagi masyarakat biasa, (4) Mempertimbangkan pendapat umum melalui proses diskusi dan debat di antara anggota komunitas, (5) Mengusahakan untuk mengunakan jurnalisme untuk mempertinggi keuntungan sosial. Pada dasarnya, tidak ada yang berubah dari kegiatan jurnalisme yang didefinisikan seputar aktivitas mengumpulkan, mengolah, dan menyebarluaskan berita. Citizen journalism pada dasarnya melibatkan kegiatan seperti itu. Hanya saja, kalau dalam pemaknaan jurnalisme konvensional (tiba-tiba saja menjadi jurnalisme old school setelah citizen journalism muncul), yang melakukan aktivitas tersebut adalah wartawan atau jurnalis, kini publik juga bisa ikut serta melakukan hal-hal yang biasa dilakukan wartawan di lembaga media. Karena itu, Shayne Bowman dan Chris Willis lantas mendefinisikan citizen journalism 
sebagai 'the act of citizens playing an active role in the process of collecting, reporting, analyzing, and disseminating news and information".

Ada beberapa istilah yang dikaitkan dengan konsep citizen journalism. Public journalism, advocacy journalism, participatory journalism, participatory media, open source reporting, distributed journalism, citizens media, advocacy journalism, grassroot journalism, sampai we-media. Civic journalism, menurut Wikipedia, bukan citizen journalism karena dilakukan oleh wartawan walau pun semangatnya tetap senada dengan public journalism, yaitu (lebih) mengabdi pada publik dengan mengangkat isu-isu publik. Citizen journalism adalah bentuk spesifik dari citizen media dengan content yang berasal dari publik. Di Indonesia, istilah yang dimunculkan untuk citizen journalism adalah jurnalisme partisipatoris atau jurnalisme warga.

J.D. Lasica, ${ }^{9}$ mengategorikan media citizen journalism ke dalam 5 tipe yaitu (1) Audience participation (seperti komenter user yang diattach pada kisah-kisah berita, blog-blog pribadi, foto, atau video footage yang diambil dari handycam pribadi, atau berita lokal yang ditulis oleh anggota komunitas), (2) Situs web berita atau informasi independen (Consumer Reports, Drudge Report, (3) Situs berita partisipatoris murni (OhmyNews), (4) Situs media kolaboratif (Slashdot, Kurohin), (5). Bentuk lain dari media 'tipis' (mailing list, newsletter e-mail), dan (6) Situs penyiaran pribadi (situs penyiaran video, seperti KenRadio). Ada dua hal setidaknya yang memunculkan corak citizen journalism seperti sekarang ini. Pertama, komitmen pada suara-suara publik. Kedua, kemajuan teknologi yang mengubah lanskap modus komunikasi.

Public journalism acap dikaitkan dengan konsep advocacy journalism karena beberapa media bergerak lebih jauh tidak saja dengan mengangkat isu, tetapi juga mengadvokasikan isu hingga menjadi sebuah 'produk' atau 'aksi'mengegolkan undang-undang, menambah taman-taman kota, membuka kelaskelas untuk kelompok minoritas, membentuk government watch, mendirikan komisi pengawas kampanye calon walikota, dan lain-lain. Public atau citizen journalism juga dikaitkan dengan hyperlocalism karena komitmennya yang sangat luar biasa pada isu-isu lokal, yang 'kecil-kecil' (untuk ukuran media mainstream), sehingga luput dari liputan media mainstream. Public journalism dengan model seperti ini mendasarkan sebagian besar inisiatif dari lembaga media. Kemajuan teknologi dan ketidakterbatasan yang ditawarkan oleh Internet membuat inisiatif semacam itu dapat dimunculkan dari konsumen atau khalayak. Implikasinya cukup banyak, tidak sekadar mempertajam aspek partisipatoris dan isu yang diangkat. Merujuk pada latar belakang dan pengertian Citizen Journalism ini sendiri, dapat disimpulkan bahwa Citizen Journalism merupakan sarana untuk mencapai suatu hal yang disebut dengan demokrasi. Hubungan jurnalisme dengan demokrasi tidak bisa di pisahkan, karena salah satu elemen dari demokrasi di suatu negara bisa dilihat dari kebebasan jurnalisme di negara tersebut. 
Kebebasan berekspresi dalam penyampaian berita tanpa ada ikatan dari pihak di luar si pembuat berita adalah hal yang ingin dicapai oleh Citizen journalisme. Jika melihat kembali sejarah yang terjadi di Indonesia, kelahiran orde reformasi pada Mei 1998 setelah Soeharto menyerahkan kekuasaannya kepada B.J Habibie yang menjadi wakil presiden saat itu menjadi titik awal demokrasi di Indonesia. Kebebasan jurnalistikpun berubah secara drastis di bandingkan masa orde baru, bisa dikatakan kemerdekaan jurnalistik.

Di era Reformasi kebebasan pers benar-benar dijamin dan senantiasa diperjuangkan untuk diwujudkan. Namun sejauh ini jika di lihat demokrasi dalam kegiatan jurnalisme belum bisa dikatakan tercapai, ini dapat dilihat dari konstitusi Indonesia yang tidak menjamin tegas kebebasan jurnalistik. Belum lagi aturan-aturan yang bersumber dalam kelembagaan media itu sendiri. Ada faktor-faktor yang mempengaruhi kehidupan media massa dalam proses peliputan hingga penyajian berita, seperti yang dipaparkan oleh Reese dan Shomaker dalam lingkaran donat yang mereka buat. Faktor-faktor tersebut antara lain faktor ideologi media, ekstra media, organisasi media, rutinitas media dan faktor individu media. ${ }^{10}$

Tentu saja hal ini mengikat seorang wartawan yang bernaung dalam sebuah lembaga media, ia harus mengikuti aturan main yang ditetapkan di tempat ia bekerja, yang akhirnya berdampak dalam kebebasannya untuk menyajikan suatu berita kepada publik. Unsur kapitalisme dan politik pun tidak bisa dihindari. Informasi yang bebas dari campur tangan pihak lain pun tidak bisa disajikan, di sinilah citizen journalisme berperan, citizen journalism yang merupakan corong jurnalisme online, yang bisa diakses melalui internet oleh siapa saja, di mana saja dan kapan saja bisa menjadi model ekspresi yang sangat kuat dan alat baru untuk mengimbangi pemerintah dan industri atau pihak-pihak besar lainnya yang berperan dalam mempengaruhi media.

Citizen journalism, menawarkan banyak hal yang membawa keuntungan bagi masyarakat, gempa dan tsunami yang disusul dengan pecahnya reaktor nuklir yang baru saja terjadi di Jepang menjadi salah satu bukti kecepatan informasi yang disediakan oleh jurnalisme online melalui citizen journalism. Hal ini membenarkan keterbukaan ruang publik yang disediakan oleh media kepada masyarakat untuk berperan aktif menyajikan, mengirimkan video dan gambar langsung dari tempat kejadian sehingga dengan cepat dapat diketahui oleh publik secara luas. Kelebihan citizen journalism salah satunya adalah kecepatan menerima informasi. Kecepatan informasi dari publik bisa membantu instansi berita menerima dan mengolah informasi. Namun karena berita-berita yang bersumber dari warga ini bersifat bebas, maka kebenaran dari informasi tersebut tidak bisa di percaya karena tidak adanya verifikasi data atau tidak dilandasi dengan kaidah-kaidah jurnalistik yang lainnya, dalam citizen journalism sebuah isu yang belum pasti kebenarannya sudah bisa di jadikan berita sehingga seringkali keabsahan berita dari citizen journalism 
dianggap lemah sebagai jurnalisme yang berkualitas. Hal ini bisa menimbulkan disinformasi bagi publik secara luas jika berita yang disampaikan ternyata tidak terbukti kebenarannya. Tentu ini bisa dimaklumi karena ketidaktahuan mengenai etika-etika dalam berjurnalistik, tidak semua orang yang berperan dalam citizen journalism mengerti bagaimana proses sebuah informasi atau isu bisa berubah menjadi sebuah berita dan menjadi layak untuk disampaikan kepada publik.

Untuk itu perlu adanya langkah-langkah yang dilakukan untuk menghindari terjadinya disinformasi yang ditimbulkan karena adanya pemberitaan yang salah oleh si pelaku citizen journalism, ini bisa dilakukan dengan mematuhi prinsip-prinsip yang telah ditetapkan dalam kaidah-kaidah jurnalistik seperti memiliki kemampuan menulis yang baik dalam artian menghindari kesalahan dalam penulisan kalimat, dan mengikuti Ejaan Yang Disempurnakan (EYD) yang ditetapkan, mempertahankan akurasi, harus mempertahankan kelengkapan data dari informasi atau berita yang ingin disajikan, kepastian akan kebenaran berita harus ditinjau kembali, menghindari subyektivitas dalam penyajian berita, harus mempunyai kepekaan dan kekritisan dalam menanggapi suatu isu, dasar-dasar jurnalisme seperti struktur atau anatomi berita, elemen berita, nilai berita sebaiknya harus di kuasai dengan baik, selain itu mengikuti standar yang telah di tetapkan oleh jurnalisme online itu sendiri misalnya dalam jumlah paragraf, kejelasan informasi, dan unsur kemenarikan tetap perlu untuk menjadi perhatian. Dengan begitu walaupun Citizen Journalism mengusung kebebasan dalam penyampaian berita, kebebasan tersebut haruslah bertanggung jawab, memang dalam Citizen Journalism tidak ada aturan yang mengatur dan menentukan harus seperti apa seseorang membuat sebuah berita atau menyajikan informasi, di sini semua orang berhak untuk menyampaikan suara dan pendapat yang menjadi aspirasinya dalam menanggapi sebuah permasalahan, isu, atau peristiwa yang sedang terjadi, namun penyalahgunaan hak berkespresi sebaiknya harus di hindari, sehingga penciptaan Citizen Journalism sebagai media demokrasi yang baik, jujur dan benar dapat tercapai.

\section{SIMPULAN}

Secara kuantitatif jurnalis perempuan masih jauh ketinggalan jika dibandingkan dengan jurnalis laki-laki walau pun sejak tahun 1904, sudah mulai bermunculan media khusus perempuan. Pada saat itu, jurnalis perempuan menggunakan media massa sebagai wahana untuk menggugah kesadaran bangsanya.

Seiring dengan kemajuan teknologi, media massa mengalami pergeseran yang pada awalnya lebih menyuarakan kepada pembebasan perempuan mulai bergeser ke arah hedonisme dan komersialisme. Akibatnya, perempuan lebih banyak menjadi bahan berita bagi sebuah media dan dianggap sebagai suatu 
komoditi yang menjanjikan keuntungan. Dalam situasi seperti ini diperlukan jurnalis-jurnalis perempuan yang berani dan mau menjunjung idealisme bukan hanya mengikuti kemauan pasar saja dan peran media yang mendidik benarbenar sangat diperlukan untuk mendongkrak dan mengangkat martabat kaum perempuan, bukan menjadikan perempuan hanya sebagai barang eksploitasi bagi media.

Di sisi lain, kemajuan teknologi informasi, menimbulkan wadah baru untuk menuangkan gagasan lewat internet dunia tanpa batas. Meski tidak berprofesi sebagai jurnalis, perempuan bisa memanfaatkan media internet untuk menyuarakan aspirasi dengan melakukan citizen journalism. Dengan demikian, keberadaan media dapat menjadi sarana bagi perempuan untuk menuangkan ekspresi dan kreasinya dalam kehidupan bermasyarakat dengan kemampuan intelektual yang dimiliki perempuan. Untuk sampai kearah tersebut, pelaku citizen journalism harus mematuhi prinsip-prinsip yang telah ditetapkan dalam kaidah-kaidah jurnalistik seperti memiliki kemampuan menulis yang baik, mempertahankan akurasi, harus mempertahankan kelengkapan data dari informasi atau berita yang ingin disajikan, kepastian akan kebenaran berita harus ditinjau kembali, menghindari subyektivitas dalam penyajian berita, harus mempunyai kepekaan dan kekritisan dalam menanggapi suatu isu, dasar-dasar jurnalisme seperti struktur atau anatomi berita, elemen berita, nilai berita sebaiknya harus dikuasai dengan baik.

\section{Endnotes:}

1 Stanley J Baran. 2010. Pengantar Komunikasi Massa, Literasi Media dan Buday. Salemba Humanika.

2 Shirley Biagi. 2010. Media/Impact, Pengantar Media Massa. Salemba Humanika

3 Sirikit Syah. 2010. Rambu-rambu Jurnalistik, dari Undang-Undang Hingga Hati Nurani. Pustaka Pelajar

4 http://www.panji.co.id/edisi perempuan dan media

5 PWI Cabang Riau. 2005. Menerobos Mitos, Seabad Pers Riau (Dari Raja Ali Kelana sampai Reformasi).

6 Bernard C Cohen. Advanced Newsgathering. karangan Bryce T McInyre

7 http://www.panji.co.id/edisi perempuan dan media

8 Lasica, dalam Online Journalism Review, 2003

9 J.D. Lasica, dalam Online Journalism Review ,2003

10 J.D. Lasica, dalam Online Journalism Review ,2003

\section{DAFTAR PUSTAKA}

Http:/ / www.panji.co.id/edisi perempuan dan media

Imam Suwandi. 2010. Langkah Otomatis Jadi Citizen Journalism. Dian Rakyat 
Luwi Ishwara. 2011. Jurnalisme Dasar. Penerbit Buku Kompas

Nurudin. 2009. Jurnalisme Masa Kini. Rajawali Pers

PWI Cabang Riau. 2005. Menerobos Mitos, Seabad Pers Riau (Dari Raja Ali Kelana sampai Reformasi).

Stanley J Baran. 2010. Pengantar Komunikasi Massa, Literasi Media dan Budaya. Salemba Humanika.

Shirley Biagi. 2010. Media/Impact, Pengantar Media Massa. Salemba Humanika

Sirikit Syah. 2010. Rambu-rambu Jurnalistik, dari Undang-Undang Hingga Hati Nurani. Pustaka Pelajar. 